\title{
Impact of the Implementation of E-Accounting in Mexico
}

\author{
Roberto Rodriguez Venegas ${ }^{1} \&$ Rafael Espinoza Mosqueda ${ }^{1}$ \\ ${ }^{1}$ Departamento de Finanzas y Administración, Universidad de Guanajuato, Campus Celaya Salvatierra, \\ Guanajuato, México \\ Correspondence: Roberto Rodriguez Venegas, Departamento de Finanzas y Administracion, Universidad de \\ Guanajuato, Guanajuato, México. Tel: 52-461-191-2747. E-mail: roberto_rodriguezv@ @otmail.com
}

Received: December 22, 2016

Accepted: January 10, 2017

Online Published: January 30, 2017

doi:10.5539/ijef.v9n3p11

URL: http://dx.doi.org/10.5539/ijef.v9n3p11

\begin{abstract}
In Mexico in 2015, a new fiscal requirement emerged called electronic accounting (e-Accounting), which consists of sending specified documents to the tax authority that form part of corporate accounting, this new requirement puts the country at the forefront of electronic accounting world-wide since the purpose is to increase tax revenue. The purpose of this study was to describe and analyze the adoption and implementation of electronic accounting by companies in Mexico and their contribution is to identify the factors that contribute to the success of the process. We applied a questionnaire to 94 companies selected at random, which correspond to individuals and corporations that had to comply with e-Accounting requirements in 2015 and 2016, where we analyzed some variables that were considered fundamental: training and specialization of the CEO, training of accounting staff, the state of computer use and technical conditions for being able to keep electronic accounting. We performed a regression analysis with 12 independent variables where the results show that the integration of balance sheet items is relevant for the process of adoption and implementation of electronic accounting (dependent variable).
\end{abstract}

Keywords: factors, e-accounting, tax obligations, implementation, enterprises

\section{Introduction}

The obligation to maintain accounting records through electronic means is born not only in order to fulfill an tax obligation, but is a response to a growing need to respond to changing globalization in business and global business transactions, which cause that documentation that integrates accounting to become increasingly voluminous, so the digitization and use of electronic media as evidence represent a solution to save space and resources for companies, while complying with the tax authority to demonstrate that all transactions made are authentic (Macias, 2014).

In Mexico, the Ministry of Finance and Public Credit apply their tax policies through the Tax Administration Service (SAT), this body indicates that electronic accounting (e-accounting) for tax purposes is 'sending files in XML format (Extensible Markup Language) of registered transactions via electronic means that a company or a person sends to their tax email account' (SAT, 2015) transactions. The obligation to submit electronic accounting comprises of preparing the following: chart of accounts, trial balance, and if required, policies and supporting documents (SAT, 2015).

The international definition of electronic accounting maintains that it is an accounting system that is based on computer technology for capturing and processing the financial information of companies, the use of technology in accounting has increased in order to produce information for administrative purposes on the basis of integrating the system of accounting information of enterprises. The most important element for implementation of electronic accounting is the use of the computer, although any electronic device may be the source (Amidu, John, \& Abor, 2011; Drew, 2015).

Previous research in this study focused on the adoption of new technologies by the company. Due to the fact that the requirement for electronic accounting by tax authorities is relatively new on national and international levels, there is scarce research on the subject. In the previous study, the subjects were Mexican companies that are required to send their electronic accounting and are considered as small and medium enterprises in Mexico, this criterion is defined by the number of employees, in addition to the company's annual sales (Secretaria de Economía, 2009). 
It is important to note that Mexico is the protagonist of a reform proposed by the OECD (Organization for Economic Co-operation and Development) on the use of new technologies to improve fiscal control of the country, which is why it is crucial for the entire international community to study the implementation measures that were taken and the obstacles encountered in its adoption. This arose from the low tax collection in Mexico, despite high tax rates, this is due to weaknesses in the application of tax legislation which are affected by the lack of fairness and transparency of the tax system (OECD, 2012). The aim of this study was to describe and analyze the adoption and implementation of electronic accounting by companies in Mexico.

The contribution of this study is that it provides the empirical evidence to facilitate the systematization of the processes and procedures of the implementation of electronic accounting in Mexican enterprises, identifying the factors (variables) to predict whether companies adopt or not e- Accounting.

\section{Literature Review}

According to Amidu, John, and Abor (2011) among the main factors that determine the practices leading to the adoption of e-accounting in a study in Ghana, are those relating to the accounting system because $79 \%$ of the sample recognized the benefits of implementing an e-accounting system, $26 \%$ of the specialization of the director of the company is marketing, and $24 \%$ have a master's degree.

Regarding the education of the director general and accounting personnel of the company, Casanovas emphasizes that senior management must be committed when trying to adopt a new model because the perception of employees of the objectives of the company is conditioned by the behavior observed in their leaders. That is why executives who enjoy professional experience and training leading to the new model to be implemented, in our case, called electronic accounting, have greater ownership of the matter and may contribute to their success (Casanovas, 2013).

With regards to those in charge of the companies' accounting department, the adoption of electronic accounting can be tiring, taking into account that the management of an accounting system, however simple, requires some training and managing ability. In addition, the requirement itself brings about a change in accounting practices commonly performed by the organization's accountant. One problem in this regard is that the accounting staff determine that the new obligation will bring more work for staff and show resistance to change and the implementation of electronic accounting, in this sense Garcia, Alamo, and Garcia-Barba (2010) highlights that employees are sometimes more reluctant to the consequences that the change brings rather than the change itself.

Given these elements, both those in charge of the accounting department in addition to all the staff comprising the accounting department must acquire and update the skills needed to enable it to respond to the obligation imposed by the SAT. The Mexican Institute of Public Accountants (2011) states that public accountants can assume that new demands placed on the environment must constantly be trained in all areas to develop in their professional work. Meanwhile, Tarmidi, Abdul, Alrazi, and Abdul (2014) indicate that more than half of staff (56\%) accept the concepts of new technologies. There are other authors who consider the influential variables that are related to the external aspects of the entity such as company size, liquidity, leverage, rate of return, and the human aspect include the audits that the company is subject to, the auditor's experience, and if they belong to a Big 4 firm (Alali \& Yeh, 2012; Berumen \& Arriaza, 2013).

Amidu, John, and Abor (2011) consider that although the proliferation of accounting software has created an opportunity for small and medium businesses to adopt e-accounting practices, concerning problems also created the adoption of innovation, businesses are trapped in two options: adopting new software that meet their needs facing the change that this entails, or keep using the software that they were already using.

Some of the problems that users see when changing accounting system is that the data needs to be converted from the existing system to the new system, representing more staff time and sometimes documents and reports must be redesigned, it is concluded that the probability of adopting a new technology depends on the size of the business, the importance awarded to this innovation, training of the manager and the type of technology involved (Amidu, John, \& Abor, 2011). Alali and Yeh (2012) argue that the nature and character of the use of technology benefit the internal control of the entity, which favors audits carried out in the company so that the results of these are positive and quick to obtain.

The cost involved in implementing a new system, often the small and medium enterprises cannot absorb the cost, so they are unable to meet the tax liability, before this Baker (2014) indicates that the choice of good accounting software starts first with the cost, the company must question whether the amount you pay for the software is proportional to the benefits received, i.e., if the company receives all you need. Other items to consider are accessibility of software, i.e., if it is available at any time for system operators, and third is the ease of use, which 
is reflected in whether or not the system is user-friendly and if there is adequate technical support to help resolve any doubt that may arise (Baker, 2014).

Furthermore, DeLone and McLean (2004) determined the factors that can influence the success of an ERP system(Enterprise Resource Planning) in six major categories: the quality of the system, the quality of information, systems in use, user satisfaction, the effect of individual and organizational impact (DeLone \& McLean, 2003). An important factor to highlight is the quality of information, which implies the importance of the handling, use and care of information for greater reliability of the data presented. The accuracy of the data is absolutely necessary for an ERP system to function properly. Due to the integrated nature of ERP, if someone enters the wrong data, the error may have a negative effect on the entire company. Therefore, educating users about the importance of the exactitude of data and entry procedures should be a priority for implementation (Stedman, 1999; Stein, 1999, cited in Umble, Haft, \& Umble, 2003).

Another factor that is involved in the process is the managerial commitment "if senior management is not strongly committed to the ERP system, it does not anticipate or plan the profound changes required by the ERP, or does not actively participate in the implementation, it has a high probability of failure since the biggest challenge for implementing ERP is related to people. At every stage, companies must work harder to manage change, retain, communicate and educate their employees" (Garg, 2010).

Bukamal and Abu Wadi (2016) cite Alsabaawi (2015) who determined 8 critical success factors in the relationship to ERP implementation which are: the commitment and support of senior management, project management, training and education of users, business plan and vision, technological infrastructure, participation of departments, change management and communication, which highlights the first category of commitment and support of senior management which involves leading the director to be more prepared, updated and have a higher degree of education, to confront the challenges of day to day.

Moreover, the applicable accounting standards in Mexico, the Financial Reporting Standards (NIF) are a set of general concepts and specific rules that regulate the elaboration and presentation of information in financial statements. NIF A-4 'Qualitative characteristics of financial statements' belongs to the conceptual framework defined as a coherent set of objectives and interrelated foundations, provides that the financial information has the quality of reliability, that when 'its content is consistent with transactions, internal changes and events that occurred, and the general user uses it to make decisions based on it. To be reliable financial information must be truthful in reflecting in the content of transactions, internal changes and other events that actually occurred, it should also be representative, objective, verifiable and contain all the information that exert influence on decision-making by general users (Consejo Mexicano de Normas de Información Financiera, AC, 2016)

For financial information to be considered representative, there must be an agreement between its content and transactions, internal changes, and events that have affected the entity financially. The financial information must be presented in an impartial manner, that is, it is not subjective nor may it be manipulated or distorted for the benefit of one or some groups or sectors that may pursue interests other than those of the general user of the financial information'. 'The adequacy of the information must be determined in relation to the common needs of the general users. Therefore, the financial information must contain sufficient evidence and basic material for decisions of general users are adequately supported' (Consejo Mexicano de Normas de Información Financiera, A.C., 2016).

\section{Method}

\subsection{Participants}

The sample of companies was selected at random at the end of 2015 throughout the state of Guanajuato and was invited to answer a questionnaire; all taxpayers included in the sample were 200 participants, of which 94 replied, accounting for $47 \%$. The sample included companies that are required to maintain electronic accounting as a new tax obligation.

Those responsible for answering the questionnaire are responsible for the accounting department of the companies, so we believe there is greater accuracy in the answers, as they are the direct contact with the changes undergone by the company following the obligation to submit accounting electronically to the portal of the Tax Administration Service (SAT).

\subsection{Questionnaire}

The questionnaire included 13 questions divided into the following sections: the type and sector of the company, training and specialization of the director general, training and specialization of the director of the accounting department, adaptability of staff in the accounting department, performance of bank reconciliation, integration 
balance sheet items, type of desktop software, cloud-based software, functionality of the accounting system, ways to improve the system, attitude on the adoption of electronic accounting and the integration of balance sheet items.

\subsection{Procedure}

First, we analyzed the literature pertaining to the adoption of ICT in companies; the study focused on factors that help or hinder the adoption of information technology; then we examined said factors, concluding with a list of items that were considered relevant. With these elements, we created a questionnaire based on the variables that help or hinder the adoption of new technologies in enterprises. However, during implementation certain questions that were not considered relevant based on the results of previous studies were eliminated, such as the age of the company, its net sales, and various financial indices (Alali \& Yeh, 2012; Berumen \& Arriaza, 2013).

For the design, it was decided that the variable integration of balance sheet items would not include the category of banks as this would form part of the study as a separate variable. The reason for this operation was based on the fact that in the descriptive results, companies show a high percentage of compliance with this accounting practice compared to levels of correcting and integrating other items of the balance sheet, and that this difference could influence the results significantly. The question was formulated to ask whether the company undertakes bank reconciliation, assuming that by complying with this rubric of banks it is corrected and integrated, due to the elements that intervene in its elaboration.

Training courses for accountants and personnel involved in the areas of corporate accounting were conducted for them to learn a little more about the issue of electronic accounting, they explained the purpose, methodology, privacy rights for information of their companies and were invited to answer the questionnaire voluntarily. During these courses, the importance of the different concepts, elements and operation of an ERP system and accounting software (which is not considered ERP) was highlighted, this was important because although all participants knew the brand management accounting software, they did not all manage the concept of ERP. Either way, for the formulation of reports to meet the electronic accounting with more or less operational work, the element of initial corrected or integrated balances are required, regardless of whether it is an ERP or accounting software.

The questionnaires were collected from October 2015 to March 2016, some questionnaires were not answered fully, and were thus eliminated. A model for analysis and subsequent discussion was designed.

\section{Results}

The results of the questions in context indicated that of the 94 companies surveyed, $78.7 \%$ are legal entities and $21.3 \%$ individuals, besides the sector where more questionnaires were answered is the services sector with $41.5 \%$, followed by the commercial sector with $39.4 \%$.

Regarding the education of the CEO, $66.7 \%$ have an undergraduate degree and $23.7 \%$ have graduate studies, while specialization results in $34.4 \%$ in accounting and $30.0 \%$ in administration (Table 1).

Table 1. Training and qualification of general manager

\begin{tabular}{clrr}
\hline & & Frequency & Percentage \\
\hline \multirow{4}{*}{ Maximum educational } & Bachelor's degree & 62 & $66.7 \%$ \\
level of the director & Postgraduate & 22 & $23.7 \%$ \\
& Baccalaureate & 4 & $4.3 \%$ \\
& Technical & 3 & $3.2 \%$ \\
& Basic & 2 & $2.2 \%$ \\
\hline & Total & $\mathbf{9 3}$ & $\mathbf{1 0 0 . 0 \%}$ \\
\hline \multirow{3}{*}{ Specialization of the } & Accounting & 31 & $34.4 \%$ \\
director & Administration & 27 & $30.0 \%$ \\
& Engineering & 22 & $24.4 \%$ \\
& Other & 10 & $11.1 \%$ \\
\hline & Total & $\mathbf{9 0}$ & $\mathbf{1 0 0 . 0 \%}$ \\
\hline
\end{tabular}

About the formation of the accounting area manager, it turns out that $62.8 \%$ of respondents have undergraduate studies, while $34 \%$ have postgraduate studies (Table 2). 
Table 2. Education of the manager of the accounting department

\begin{tabular}{clcc}
\hline & & Frequency & Percentage \\
\hline & Bachelor's degree & 59 & $62.8 \%$ \\
& Postgraduate & 32 & $34.0 \%$ \\
Maximum educational level of the manager of & Basic & 1 & $1.1 \%$ \\
the accounting department & Baccalaureate & 1 & $1.1 \%$ \\
& Technical & 1 & $1.1 \%$ \\
& Total & $\mathbf{9 4}$ & $\mathbf{1 0 0 . 0 \%}$ \\
\hline
\end{tabular}

As for the specialization of the individual responsible for the accounting area most, have a specialty in accounting $(62.8 \%)$ and almost a third in tax (29.8\%) (Table 3).

Table 3. Specialization of manager of the accounting department

\begin{tabular}{lccc}
\hline & \multicolumn{2}{c}{ Yes } & \multirow{2}{*}{ Total companies } \\
\cline { 2 - 3 } & Frequency & Percentage & \\
\hline Accounting & 59 & $62.8 \%$ & 94 \\
Fiscal & 28. & 29. & 94 \\
Accounting and auditing & 13. & 13. & 94 \\
Finance & 6. & 6. & 94 \\
Governmental & 1 & $1.1 \%$ & 94 \\
\hline
\end{tabular}

Note. The \% is not totaled because they are independent items.

As for the staff of the accounting department, we asked whether employees in the department adapt easily to change. We found that $70.3 \%$ of companies believe that their staff adapt easily to change, while $29.7 \%$ think that they do not (Table 4).

Table 4. Adaptability of staff in the accounting area

\begin{tabular}{clcc}
\hline & & Frequency & Percentage \\
\hline Do department staff adapt easily to change? & Yes & 64 & $70.3 \%$ \\
& No & 27 & $29.7 \%$ \\
& Total & $\mathbf{9 1}$ & $\mathbf{1 0 0 . 0 \%}$ \\
\hline
\end{tabular}

Participants were also questioned about the necessary requirements prior to carrying out electronic accounting, including whether perform monthly bank reconciliations and we obtained as a very high $94.4 \%$ application of this accounting practice (Table 5).

Table 5. Performing bank reconciliations

\begin{tabular}{cccc}
\hline & & Frequency & Percentage \\
\hline \multirow{2}{*}{ Does the company conduct bank reconciliations every } & Yes & 85 & $94.40 \%$ \\
month? & No & 5 & $5.60 \%$ \\
& Total & $\mathbf{9 0}$ & $\mathbf{1 0 0 \%}$ \\
\hline
\end{tabular}

The accounting practice of keeping correct and integrated accounts is the most important skill of maintaining the Balance Sheet or Statement of Financial Position, showing that the integration of balance sheet items is corrected by $54 \%$ and not corrected by $46 \%$ on average. Fixed assets with a $59.3 \%$ show the highest percentage of correction and the lowest inventories with $42.3 \%$ (Table 6 ).

Table 6. Integration of balance sheet items

\begin{tabular}{|c|c|c|c|c|c|c|}
\hline & \multicolumn{2}{|c|}{ Without correction } & \multicolumn{2}{|c|}{ Corrected } & \multicolumn{2}{|c|}{ Total } \\
\hline & fr. & $\%$ & fr. & $\%$ & fr. & $\%$ \\
\hline Accounts receivable (clients) & 39 & $44.8 \%$ & 48 & $55.2 \%$ & 87 & $100 \%$ \\
\hline Other accounts receivable (various debtors, etc.) & 42 & $50.0 \%$ & 42 & $50.0 \%$ & 84 & $100 \%$ \\
\hline Inventories & 45 & $57.7 \%$ & 33 & $42.3 \%$ & 78 & $100 \%$ \\
\hline Fixed assets & 35 & $40.7 \%$ & 51 & $59.3 \%$ & 86 & $100 \%$ \\
\hline Accounts payable to suppliers & 36 & $44.4 \%$ & 45 & $55.6 \%$ & 81 & $100 \%$ \\
\hline
\end{tabular}




\begin{tabular}{|c|c|c|c|c|c|c|}
\hline The other payables (bank loans, various creditors, taxes payable) & 36 & $42.4 \%$ & 49 & $57.6 \%$ & 85 & $100 \%$ \\
\hline Capital accounts & 37 & $44.0 \%$ & 47 & $56.0 \%$ & 84 & $100 \%$ \\
\hline Total & 270 & $46 \%$ & 315 & $54 \%$ & 585 & \\
\hline
\end{tabular}

In the aspect of the computer, we found that most of the companies surveyed use a desktop software or local server for their operations obtaining the following types of systems (Table 7).

Table 7. Types of desktop software

\begin{tabular}{lccc}
\hline & \multicolumn{2}{c}{ Yes } & \multirow{2}{*}{ Total companies } \\
\cline { 2 - 3 } & Frequency & Percentage & 94 \\
CONTPAQi & 70 & $74.50 \%$ & 94 \\
Other & 13 & $13.80 \%$ & 94 \\
Aspel & 9 & $9.60 \%$ & 94 \\
Microsip & 4 & $4.30 \%$ & 94 \\
\hline
\end{tabular}

Note. The $\%$ is not totaled because they are independent items.

There is a wide range of cloud-based software, as the choice other software has the highest frequency (Table 8).

Table 8. Types of software in the cloud

\begin{tabular}{lccc}
\hline & \multicolumn{2}{c}{ Yes } & \multirow{2}{*}{ Total companies } \\
\cline { 2 - 3 } & Frequency & Percentage & 94 \\
\hline Other & 11 & $11.70 \%$ & 94 \\
Sinube & 7 & $7.40 \%$ & 94 \\
PFF Crol & 6 & $6.40 \%$ & 94 \\
click balance & 1 & $1.10 \%$ & 9 \\
\hline
\end{tabular}

Note. The $\%$ is not totaled because they are independent items.

The effectiveness of the system is analyzed for obtaining registration of operations that $58.2 \%$ of companies registered their operations within 30 days and $25.3 \%$ recorded online (Table 9).

Table 9. Functionality accounting system

\begin{tabular}{clcc}
\hline & & Frequency & Percentage \\
\hline & Within 30 days & 53 & $58.2 \%$ \\
Period in which the accounting & Online & 23 & $25.3 \%$ \\
entries are made daily operations & After 30 days & 8 & $8.8 \%$ \\
& Sometimes within 30 days & 7 & $7.7 \%$ \\
& Total & $\mathbf{9 1}$ & $\mathbf{1 0 0 . 0 \%}$ \\
\hline
\end{tabular}

The surveyed companies raised a number of ways that they consider would improve the accounting system used, preponderant is fast system upgrades with $53.2 \%$ and proper reporting of financial statements with $37.2 \%$ (Table $10)$.

Table 10. Ways to improve the system

\begin{tabular}{lccc}
\hline & \multicolumn{3}{c}{ Yes } \\
\cline { 2 - 3 } & Frequency & Percentage & \\
\hline Fast system updates & 50 & $53.2 \%$ & 94 \\
Appropriate reporting of financial statements & 35 & $37.2 \%$ & 94 \\
Perform operations on multiple windows simultaneously & 29 & $30.9 \%$ & 94 \\
Other & 8 & $8.5 \%$ & 94 \\
\hline
\end{tabular}

Later, we asked about the attitude of staff towards the adoption of electronic accounting; we found that $63.7 \%$ of respondents adopt electronic accounting because they recognize its benefits, and $36.3 \%$ will not until it becomes inevitable (Table 11). 
Table 11. Attitude on the adoption of electronic accounting

\begin{tabular}{clcc}
\hline & & Frequency & Percentage \\
\hline \multirow{3}{*}{$\begin{array}{c}\text { Attitude of the company on the } \\
\text { adoption of EA }\end{array}$} & It will adopt the EA as it recognizes the benefits & 58 & $63.7 \%$ \\
& It will not adopt the EA until it is unavoidable to do so & 33 & $36.3 \%$ \\
\hline
\end{tabular}

\subsection{Logistic Regression}

A logistic regression analysis was performed to predict whether or not electronic accounting would be adopted by businesses. We used all the selected variables as predictors and performed simple logistic regressions to find the best predictors for multiple logistic regression; the FORWARD method was used, the integration of balance sheet items was the only significant predictor (Wald $=3.639, \mathrm{p}<0.05$ ), the significance of the full model was tested using the test called SPSS 'model Chi-square', this indicates that the suggested model is significant to two decimal places (Chi-square $=3.73, \mathrm{p}=0.05, \mathrm{df}=1$ ), the test of goodness of fit by Hosmer-Lemeshow was not significant $($ Chi-square $=1.81, \mathrm{p}>0.05, \mathrm{df}=4)$, implying that the estimated model fits the data acceptably.

For a correct interpretation of the model, we considered that the values (items) taken by the independent variable in the model have the same degree of difficulty in compliance so that variable is considered to be numeric in the number. The odd ratio indicates that companies that increase the integration of a balance sheet item are 1.16 times more likely to comply with sending electronic accounting firms than those firms that do not increase them (Table 12).

Table 12. Multiple logistic regression analysis to predict the adoption of electronic accounting based on balance sheet items

\begin{tabular}{|c|c|c|c|c|c|c|c|}
\hline & & & & & & \multicolumn{2}{|c|}{ 95\% C.I. for Odds Ratio } \\
\hline & $\beta$ & $S E \beta$ & Wald & $p$ & Odds Ratio & Lower & Upper \\
\hline Integration of balance sheet items & .149 & .078 & 3.639 & .048 & 1.161 & 1.100 & 1.353 \\
\hline Constant & -.024 & .351 & .005 & .946 & .977 & & \\
\hline Test & & \multicolumn{2}{|c|}{ chi square } & $d f$ & $p$ & & \\
\hline \multicolumn{8}{|l|}{ Overall evaluation model } \\
\hline Model Chi-square & & \multicolumn{2}{|c|}{3.731} & 1 & 0.053 & & \\
\hline \multicolumn{8}{|l|}{ Goodness-of-fit test } \\
\hline Hosmer \& Lemeshow & & \multicolumn{2}{|c|}{1.81} & 4 & 0.771 & & \\
\hline Cox and Snell $R 2=0.043, R 2=0$. & & & & & & & \\
\hline
\end{tabular}

The graph of integration of balance sheet items (x-axis) against the predictive probability model (y-axis) shows an increase of $24 \%$ in compliance with electronic accounting if they do not integrate nor correct any item to meet to integration and correction of all items. As shown in the graph, the first to the seventh item of the balance values are respectively: $.531, .568, .604, .639, .673, .705$, and .735 possibilities to comply with submitting electronic accounting (Figure 1).

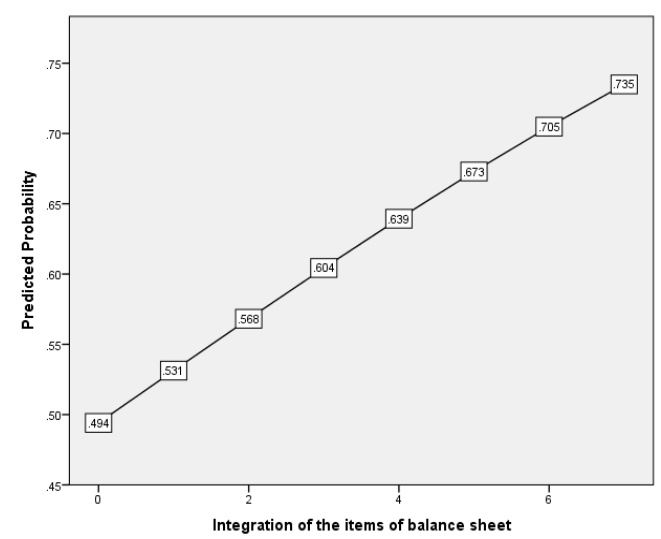

Figure 1. Integration of balance sheet items 


\section{Discussion and Conclusions}

This study contributes to the knowledge, since through the identification and studies of the factors that intervene in the process of implementation of e-accounting in Mexican companies, empirical evidence has been obtained that the quality of the data of each item of the balance that is entered into the system contributes in a relevant way to the success of the process.

A study was conducted to describe the aspects related to the implementation of electronic accounting in Mexico. In order to do this, we applied a questionnaire to 94 companies that are obligated to submit their accounts electronically in the state of Guanajuato Mexico, analyzing some variables that were considered essential: vocational training of the director general, training of accounting personnel, the status of computer use, and technical conditions to carry electronic accounting.

Through multiple regression analysis we found that in the process of adoption and implementation of electronic accounting, each item of the balance sheet showing the financial position of the company that is refined and integrated contributes significantly to this process in relation to companies that have not corrected or integrated those items.

Therefore, it is important that any company that initiates or is in the process considers it as a measure that will fulfill the obligation to submit electronic accounting and in a broad sense. In this sense, it is reasonable to conclude that companies should completely correct and integrate all the items making up the balance before starting implementation, as this measure contributes to the efficiency and effectiveness of the process.

This finding is consistent with DeLone and McLean (2004) who determined that one of the six important dimensions for the use of an ERP is the quality of the information entered into the system because the accuracy of the data is absolutely essential for its proper functioning. Moreover, Mexican financial reporting standards within the conceptual framework must consider a qualitative characteristic that characterizes financial information, which is reliability. To be reliable, financial information must be a truthful reflection on the content of transactions, internal changes and other events that actually occurred; it should also be representative, objective, verifiable and contain all the information that exerts influence on the decision-making of general users. The international financial reporting standards (IFRS) are consistent in this regard.

Thus, it is reasonable to conclude that prior to the commencement of the implementation of electronic accounting, it requires that all items are fully corrected and integrated for effective operation under the new technological and accounting models on which they are based. That is why a barrier to the adoption of electronic accounting is that companies do not correct and integrate the opening balances of the items of financial information prior to the start of the implementation of electronic accounting. As a consequence, correction work must be repeated, which directly affects higher costs and longer time to achieve the objective. A previous audit or specific job that would ensure the accuracy of the initial information is a convenient way to ensure correct data input.

In this regard, Méndez (2009) believes that the application of information technology to the business has two main purposes, first, faster recording to more up-to-date information and secondly the ease of transferring information to external and suppliers, customers and regulators. It is believed that cloud accounting systems facilitate registration information online.

As for the results of descriptive variables, it can be concluded that almost all surveyed companies have a CEO who has undergraduate level studies $(66.7 \%)$, followed by $23.7 \%$ with postgraduate degrees. In the study conducted in Ghana by Amidu, John, and Abor (2011), the highest level of studies of the director general is postgraduate with $24 \%$, which coincides with regards to postgraduate, but not the maximum degree of studies.

Casanova (2013) supports this position, and says that those companies that have a CEO or a leader who belongs to the area where change comes in the organization can more easily adapt to the new model, that is, those companies that have directors who are specialists in the accounting and tax area will be those that are most successful in the implementation of electronic accounting.

Also in the field of personnel, most companies have the belief that their employees adapt easily to change that the implementation of electronic accounting represents (70.3\%), this differs from the results obtained in Tarmidi, Abdul, Alrazi, \& Abdul (2014) who determined 56\% for this variable.

Another important element of the present study was the state of computer use, which gave us basic guidelines for understanding the time that companies keep on sending their information to the Tax Administration Service. Of the companies surveyed, most companies use a desktop accounting system, which causes companies to carry out the accounting records after 30 days. 
The above represents a major disadvantage in business because of the technical and specific requirements for sending electronic accounting requirements cause that recordkeeping be carried out practically online for the proper fulfillment of the obligation, which a large part of the companies are not fulfilling. An important finding in the results showing accounting practices as the preparation of bank reconciliation is nearly full compliance. In contrast, maintaining correct and integrated inventory has the lowest compliance rate. The remaining rubrics regarding the accounts receivable from clients, other receivables, accounts payable, capital accounts show an average compliance.

Despite the importance of electronic accounting and its widespread use, there has been relatively little research on the subject, so this study helps to fill the gap on the issue of the adoption of electronic accounting in Mexico, by analyzing variables that are significant in previous studies, affect the application of accounting electronics companies, such as vocational training of the director general, training of accounting personnel, the status of computer use and the challenges of the accounting system.

It is considered that for Mexican taxpayers to comply with this new obligation, they must make adjustments to their accounting systems and personnel responsible for generating accounting information in enterprises. While the Mexican government took this step to streamline and improve tax collection, there are different elements that cast doubt on the adoption of this innovation within the time required; the above is due to the administrative burden for companies to comply with this new provision. It is noteworthy that this study helps the international community to learn the process followed in Mexico in the implementation of electronic accounting, and also serves as a basis for those countries in the future, following the international trend to adopt the use of electronic accounting.

Finally, we should note the limitations of this study, being descriptive we included in certain sections empirically; it was impossible to include all questions of extension of the study, and consequently, the questionnaire applied. Being a new and unprecedented study, comparisons under similar conditions of trends and relationships were limited.

For these reasons, future research should be conducted with a larger sample to be able to generalize the results. Further studies to validate the findings in this work and make improvements by adding, removing and modifying the items, so that cause and effect may be established or apply existing instruments that include a wide range of dimensions to evaluate.

\section{Acknowledgement}

The author wish to thank the Directorate for Research Support and Postgraduate Programs at the University of Guanajuato for their support in the translation and editing of the English-language version of this article.

\section{References}

Alali, F., \& Yeh, C. L. (2012). Cloud Computing: Overview and Risk Analysis. Journal of Information Systems, 13-33. https://doi.org/10.2308/isys-50229

Amidu, M., John, E., \& Abor, J. (2011). E-Accounting Practices among Small and Medium Enterprises in Ghana. Journal of Management Policy and Practice, 145-155.

Baker, G. (2014). Ledgers in the cloud. The Owner Manager's Magazine, 26-32.

Berumen, S., \& Arriaza, K. (2013). Medición de la intensidad en el uso de las tecnologías de la información y la

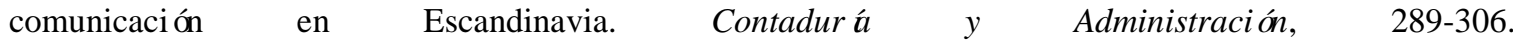
https://doi.org/10.1016/S0186-1042(13)71206-3

Bukamal, O., \& Abu Wadi, R. (2016). Factors Influencing the Success of ERP System Implementation in the Public Sector in the Kingdom of Bahrain. International Journal of Economics and Finance. http://dx.doi.org/10.5539/ijef.v8n12p21

Casanovas, A. (2013). Resistencia al cambio y conductas obstructivas. Serie de Cuadernos Sobre Cumplimiento Legal, 3-30.

Consejo Mexicano de Normas de Información Financiera, A. C. (2016). Normas de Información Financiera. México: Instituto Mexicano de Contadores Públicos, A.C.

DeLone, W., \& McLean, E. (2003). The DeLone and McLean model of information systems success: A ten-year Update. Journal of Management Information Systems, 9-30.

Drew, J. (2015). Accounting firms moving slowly toward cloud. Journal of Accountancy, 1-6.

García, A. M., Álamo, F. R., \& García-Barba, F. (2011). Antecedentes de la resistencia al cambio: Factores 
individuales y contextuales. Cuadernos de Economíay Direccióndela Empresa, 231-246. https://doi.org/10.1016/j.cede.2011.02.007

Garg, P. (2010). Critical failure factors for enterprise resource planning implementations in Indian retail organizations: An exploratory study. Journal of Information Technology Impact, 35-44.

Guajardo, G. (2013). Contabilidad financiera. México: Mcgraw-Hill Interamericana.

Hernandez, M. A., Galindo, M. I., \& Hernandez, J. (2015). Estudio práctico de la contabilidad electrónica. México: ISEF.

Instituto Mexicano de Contadores Públicos, A. C. (2011). Normas de auditoría, para atestiguar, revisión y otros servicios relacionados. In E. Calvillo Sánchez (Ed.), Distrito Federal. México: Instituto Mexicano de Contadores Públicos, A.C.

Macias, V. T. F. (2014). Medios electrónicos en materia fiscal. México: Editorial Progreso S.A de C.V.

OCDE. (2012). Getting It Right. Una agenda estratégica para las reformas de México. México: OECD Publishing.

Secretaria de Economía. (30 de 06 de 2009). Diario Oficial de la Federación. Obtenido de http://dof.gob.mx/nota_detalle.php?codigo=5096849\&fecha=30/06/2009

Servicio de Administración Tributaria. (20 de Marzo de 2016). Servicio de Administración Tributaria. Obtenido de Contabilidad electrónica: http://www.sat.gob.mx/fichas_tematicas/buzon_tributario/Paginas/contabilidad_electronica.aspx

Tarmidi, M., Abdul, S. Z., Alrazi, B., \& Abdul, R. (2014). Cloud computing awareness and adoption among accounting practitioners in Malaysia. International Conference on Accounting Studies, 569-574. http://dx.doi.org/10.1016/j.sbspro.2014.11.147

Umble, E., Haft, R., \& Umble, M. (2003). Enterprise Resource Planning: Implemetation Procedures and Critical Success Factors. European Journal Operational Research, 241-257. http://dx.doi.org/10.1016/S0377-2217(02)00547-7

\section{Copyrights}

Copyright for this article is retained by the author(s), with first publication rights granted to the journal.

This is an open-access article distributed under the terms and conditions of the Creative Commons Attribution license (http://creativecommons.org/licenses/by/4.0/). 